\title{
Energy analysis of the performance of a hybrid solar still composed of a parabolic concentrator with PV generator
}

\author{
Benaissa Mandi ${ }^{1} \cdot$ Younes Menni ${ }^{1} \cdot$ Houari Ameur $^{2}$
}

Received: 5 September 2020 / Accepted: 20 January 2021 / Published online: 2 February 2021

(c) The Author(s) $2021 \quad$ OPEN

\begin{abstract}
In this study, a hybrid system with the addition of a greenhouse solar still is proposed to improve the efficiency, performance, and productivity of solar still. The energy analysis is performed with the help of a computer program using a set of typical design and operating parameters. The result showed that the hybrid still coupled with a PCC (parabolic cylindrical concentrator) can produce $110 \mathrm{l} / \mathrm{m}^{2}$ per day. The temperatures of the basin and water of the hybrid still with PCC are 140 and $100^{\circ} \mathrm{C}$, respectively. The causes are the several sources of temperatures are added together in a single system. The obtained values of efficiency, production, and performance are $160 \%, 100 \mathrm{l} / \mathrm{m}^{2}$, and 2 , respectively. The results show also that the temperature and production in the month of January are $70{ }^{\circ} \mathrm{C}$ and $50 \mathrm{I} / \mathrm{m}^{2}$ per day, respectively, despite the negative influence of meteorological parameters. The performance of the suggested hybrid still is found to be higher than that of the single still without a concentrator.
\end{abstract}

Keywords Hybrid solar distiller · Photovoltaic system · Parabolic concentrator · Overall efficiency · Energy production

\begin{tabular}{|c|c|c|c|}
\hline \multicolumn{2}{|c|}{ Abbreviations } & \multirow{3}{*}{$h_{w-g}^{e v}$} & \multirow{2}{*}{$\begin{array}{l}\text { Heat exchange coefficient by condensa- } \\
\text { tion-evaporation between the glass and }\end{array}$} \\
\hline$A_{b}$ & Area of the basin $\left(\mathrm{m}^{2}\right)$ & & \\
\hline$A_{w}$ & Area of the water $\left(\mathrm{m}^{2}\right)$ & & water film \\
\hline$A_{g}$ & Area of the glass cover $\left(\mathrm{m}^{2}\right)$ & $h_{i s e-a}^{r}$ & Heat exchange coefficient by radiation \\
\hline$B w$ & $\begin{array}{l}\text { Coefficient of volumetric expansion of } \\
\text { water }\end{array}$ & & $\begin{array}{l}\text { between the insulation and the outside air } \\
\text { Heat exchange coefficient by radiation }\end{array}$ \\
\hline$C_{p, g}$ & Specific heat of the glass $\left(\mathrm{J} / \mathrm{kg}^{\circ} \mathrm{C}\right)$ & & between the glass and water film \\
\hline$C_{p, w}$ & Specific heat of the water $\left(\mathrm{J} / \mathrm{kg}^{\circ} \mathrm{C}\right)$ & IG & Solar irradiation $\left(\mathrm{W} / \mathrm{m}^{2}\right)$ \\
\hline Eprod (wh) & Electric energy produced (W) & $K_{v}$ & Coefficient of extinction of the glass $\left(\mathrm{m}^{-} 1\right)$ \\
\hline Gr & Number de Grashof & $L$ & Length of the absorbent tray \\
\hline 9 & Acceleration $\left(\mathrm{m}^{2} / \mathrm{s}\right)$ & $L_{w}$ & Latent heat of vaporization. \\
\hline$h_{b-w}^{c}$ & Coefficient of heat transfer by convection & $m$ & Mass (kg) \\
\hline$h_{g-a}^{c}$ & $\begin{array}{l}\text { Coefficient of heat transfer by convection } \\
\text { between the glass and outdoors }\end{array}$ & $\begin{array}{l}m_{A} \\
M_{c}\end{array}$ & $\begin{array}{l}\text { Mass flow rate }(\mathrm{kg} / \mathrm{s}) \\
\text { Mass of the condensate }\end{array}$ \\
\hline$h_{i s e-w}^{c}$ & $\begin{array}{l}\text { Coefficient of heat transfer by convection } \\
\text { between the insulation and the outside air }\end{array}$ & $\begin{array}{l}M_{\mathrm{b}} \\
M_{\mathrm{w}}\end{array}$ & $\begin{array}{l}\text { Molecular weight } \\
\text { Molecular weight }\end{array}$ \\
\hline$h_{g-a}^{c}$ & $\begin{array}{l}\text { Coefficient of heat transfer by radiation } \\
\text { through the glass to the outside }\end{array}$ & $\begin{array}{l}M_{g} \\
N(h)\end{array}$ & $\begin{array}{l}\text { Molecular weight } \\
\text { Number of hours of exposure of module }\end{array}$ \\
\hline
\end{tabular}

$\triangle$ Benaissa Mandi, mandi.benaissa@outlook.com | ${ }^{1}$ Unit of Research On Materials and Renewable Energies, Department of Physics, Faculty of Sciences, Abou Bakr Belkaid University, P.O. Box 119, 13000 Tlemcen, Algeria. ${ }^{2}$ Department of Technology, University Centre of Naama, P.O. Box 66, 45000 Naama, Algeria. 


\begin{tabular}{|c|c|c|c|}
\hline$P_{\mathrm{b}}$ & Solar power absorbed by the basin $\left(\mathrm{W} / \mathrm{m}^{2}\right)$ & $T_{\text {gi }}$ & Glass cover temperature $\left({ }^{\circ} \mathrm{C}\right)$ \\
\hline$P_{c}(w)$ & Peak power & $m_{A}$ & Mass flow rate $(\mathrm{kg} / \mathrm{s})$ \\
\hline$P_{\mathrm{g}}$ & Solar power absorbed by the glass $\left(\mathrm{W} / \mathrm{m}^{2}\right)$ & $m$ & Thickness of the water film (I/min) \\
\hline$P_{v}^{g} \mathrm{gi}$ & Spray pressure to $T_{g i}$ & $r$ & Electrical resistance (ohm) \\
\hline $\operatorname{Pr}$ & Prandtl number & I & Current intensity (Ampere) \\
\hline $\begin{array}{l}P_{v}^{w} \\
P^{w}\end{array}$ & $\begin{array}{l}\text { Spray pressure to } T_{w} \\
\text { Solar power absorbed by the water }\left(\mathrm{W} / \mathrm{m}^{2}\right)\end{array}$ & $Q_{\mathrm{ev}}$ & $\begin{array}{l}\text { Amount of heat used for evaporation per } \\
\text { unit of time (useful gain) }\left(\mathrm{W} / \mathrm{m}^{2}\right)\end{array}$ \\
\hline $\begin{array}{l}Q_{p 24 h} \\
Q_{E 24 h}\end{array}$ & $\begin{array}{l}\text { Quantity of water produced after } 24 \mathrm{~h} \\
\text { Quantity of energy entered after } 24 \mathrm{~h}\end{array}$ & $L_{v}$ & $\begin{array}{l}\text { Latent heat of vaporization (evaporation } \\
\text { enthalpy) }(\mathrm{kJ} / \mathrm{kg})\end{array}$ \\
\hline$Q_{c b-w}$ & $\begin{array}{l}\text { Convective heat flux between the bin and } \\
\text { the water }\end{array}$ & $\begin{array}{l}m_{\mathrm{d}} \\
G\end{array}$ & $\begin{array}{l}\text { The mass flow rate of distillate }(\mathrm{kg} / \mathrm{s}) \text {. } \\
\text { Incident solar radiation power per unit area }\end{array}$ \\
\hline$Q_{b-i s i}^{c d}$ & Heat flow lost by conduction & & $Q_{\mathrm{ev}}$ \\
\hline$Q_{w-g}^{c-i s t}$ & $\begin{array}{l}\text { Heat flow by convection between the } \\
\text { water and glass. }\end{array}$ & $I_{G} \times A_{g}$ & Total incident solar radiation \\
\hline
\end{tabular}

$Q_{g-a}^{c} \quad$ Heat flow lost by convection through the glass to the outside

$Q_{w-g}^{e v} \quad$ Heat flow by condensation-evaporation between the glass and water film

$Q_{g-a}^{r} \quad$ Heat flow lost by the glass by radiation outward

$Q_{w-g}^{r} \quad$ Heat flow by radiation between water and glass

$R_{D} \quad$ Characteristic of the reflectivity of the glass

$R_{w} \quad$ Coefficient of reflection of the brine

$T_{a} \quad$ Ambient temperature

$T_{b} \quad$ Basin temperature $\left({ }^{\circ} \mathrm{C}\right)$

$T_{\text {ise }} \quad$ Temperature of the external insulation

$T_{i s i} \quad$ Temperature of the inner insulation

$T_{g} \quad$ Glass cover temperature $\left({ }^{\circ} \mathrm{C}\right)$

$T_{\text {sky }} \quad$ Temperature of the sky

$T_{\mathrm{w}} \quad$ Water temperature $\left({ }^{\circ} \mathrm{C}\right)$

$T_{\text {ele }} \quad$ Temperature converted by the photovoltaic $\left({ }^{\circ} \mathrm{C}\right)$

$\lambda_{\text {iso }} \quad$ Conductivity of the insulation.

$\lambda_{g} \quad$ Thermal conductivity of the glass

$\sigma \quad$ Constant of Stefan-Boltzmann

$\varepsilon_{w} \quad$ Water emissivity

$\varepsilon_{g} \quad$ Emission of the glass

$\rho \quad$ The density of water $\left(\mathrm{kg} / \mathrm{m}^{3}\right)$

$\delta_{g} \quad$ Thickness of the glass

$\delta_{i s o} \quad$ Thickness of the insulation

$\delta_{v} \quad$ Thickness of the glass (m)

$\tau_{D} \quad$ Thickness of the glass

$\tau_{w} \quad$ Coefficient of transmission of brine

$\rho_{r} \quad$ Transmission coefficient due to reflection

$\alpha_{a} \quad$ Due to the absorption coefficient of transmission

$\alpha_{w} \quad$ Absorption factor of the brine (constant)

$\alpha_{b} \quad$ Coefficient of absorption by the basin

$h_{w-g}^{c} \quad$ Heat exchange coefficient by convection between the glass and water film

$P_{v^{w i}} \quad$ Spray pressure to $T_{w}$

SN Applied Sciences

\section{Introduction}

The solar distillation is a simple technology that keeps the environment clean. It presents a promising alternative for saltwater desalination that can partially meet humanity's freshwater needs with free energy [1]. Harnessing solar energy is a way to protect the environment and the economy [2]. This technique is presented in arid areas where rainfall is scarce. It is necessary to increase the production and efficiency of solar still. For this purpose, researchers have sacrificed laudable efforts to improve solar still.

Researchers have done extensive research in the past to increase the water production from the conventional solar still. In addition, the solar still is the efficient way to obtain fresh water where the annual precipitation is insufficient [3]. Frick and Sommerfield. [4] built a wick solar still to raise the water temperature and improve the evaporation rate. Tiwari et al. [5] manufactured a double-wicking solar still with condensation. Somwanshi and Tiwari. [6] proposed casting water cooled to the temperature of the wet thermometer, from the reservoir of a cooler poured over the glass cover of a single-slope active still. The yield was between 41.3 and $56.5 \%$ for various climate regions in India. Hosseini et al. [7] integrated a solar distillation system with the concentrator and a vacuum heat exchanger (HE). They explored the influence of the operational and environmental parameters on the overall efficiency. An increase in hot losses and a reduction in the exergy and energy performances may be resulted from the inappropriate insulating cover of the HE.

Elbar and Hassan [8] presented a novel integration of PV with the solar still and the use of phase change material (PCM) for thermal energy storage. The results indicated that integrating PV with the conventional solar still (CSS) increases its productivity by $9 \%$. Using PCM with the still coupled with PV increases the daily yield to $11.7 \%$. Elbar and Hassan [9] studied experimentally the improvement of the hybrid solar desalination system consisting of 
a solar panel integrated with a solar still. They used porous materials and salt water preheating. The results showed that preheating $40 \%, 50 \%$ and $60 \%$ of the salt water increases the efficiency of the solar freshwater desalination system to $10.4 \%, 15.5 \%$ and $20.9 \%$, and its efficiency of $8.2 \%, 13 \%$ and $20 \%$, respectively. The first kind of solar stills (i.e., the active) has been the subject of numerous research studies Among other works, Mazraeh et al. [10] studied numerically the efficiency of a solar still connected with solar panel and PCM unit. Hedayati-Mehdiabadi et al. [11] investigated the efficiency of a combined PCM unit and PV/T collector with a double-slope still. They observed an increase in the exergy performance by $27 \%$ in comparison with CSS. The maximum amount of power output and the produced water were $470 \mathrm{~W} \cdot \mathrm{h} / \mathrm{m}^{2}$ and $6.5 \mathrm{~kg} /$ $\mathrm{m}^{2}$, respectively. The review study conducted by Manokar et al. [12] on the combination of solar distiller with PV/T revealed that the energy efficiency may be increased and the cost of fixing PV panels may be reduced through the use of solar panel instead of side walls of solar still. Pounraj et al. [13] combined Peltier heater and PV/T with a solar distiller. In comparison with traditional still, the presence of Peltier heater yielded an augmentation in water temperature by $52 \%$, which resulted an increase in the freshwater productivity by 6.5 times over that produced by the traditional still. Saeedi et al. [14] optimized the number of $P V / T$ collectors combined with solar still to reach the highest energy performance, output electrical power, and freshwater yield. In comparison with traditional still, Johnson et al. [15] obtained an enhancement in the production of potable water by $638 \%$ through the used a Fresnel Lens.

Winston et al. [16] inspected the performance of solar distiller combined with a $\mathrm{NiCr}$ spiral wire heater and a $\mathrm{PV} / \mathrm{T}$ collector. Furthermore, Rajaseenivasan et al. [17] analyzed the effect of water agitation and its height on the performance of solar panels having paraffin wax as PCM combined with solar still. The most significant output of the suggested combination was $5.23 \mathrm{~kg} / \mathrm{m}^{2}$ day. The integration of thermoelectric cooler with active still allowed an enhancement in the overall performance by 3.2 times over than traditional still, as found by Rahbar et al. [18]. Additionally, Kargarsharifabad et al. [19] examined the efficiency of combined flat plate collector with a heat pipe.

Effects of the depth of bottom channel on the efficiency of stepped solar still combined with $\mathrm{PV} / \mathrm{T}$ collector were inspected by Xiao et al. [20]. The maximum enhancements in exergy performance, energy performance, and freshwater yield were 3,17 , and $51.7 \%$ at a depth of $0.01 \mathrm{~m}$, respectively. Moreover, the numerical study conducted by Alipanah and Rahbar [21] on the influence of geometrical parameters like the number of steps and the step height (h) on the efficiency of stepped active still indicated that the highest water yield was reached with 7, 8, and 10 steps still, when $h=2 \mathrm{~cm}$. The comparative study achieved by Rahbar et al. [22] on triangular and tubular active stills illustrated the superiority of tubular ones by $20 \%$ in terms of freshwater productivity.

This study is devoted to improving the production of solar distiller, which is based on the greenhouse effect. For this purpose, solar systems that can transform the solar rays into additional energy are used in this study. These systems serve to increase the evaporation, production, and overall efficiency. In the knowledge of authors, the case studied here has not been explored previously.

The paper is organized as follows: the system under investigation is described in Sect. 2; then, the mathematical background and the governing parameters of the physical problem are presented in details in Sect. 3. In Sect. 4, the obtained results are analyzed and discussed.

\section{System under investigation}

The proposed system shown in Fig. 1 is an ordinary single-basin still coupled with a photovoltaic generator. The entire system is coupled with a solar parabolic concentrator to increase the thermal energy inside the distiller. The greenhouse effect stillness collects the pond absorbs solar radiation (SR). The solar radiation passes through the glass cover into the basin saline water. The saline water is heated by the incident solar radiation that is absorbed and converted into thermal energy. Consequently, the evaporation of saline water begins, and some of the water vapor will be condensed on the glass inner surface. It is coupled with a PV system containing the following cells:

- Solar panels are used to convert the rays of the sun into electrical energy.

- Stationary batteries to ensure the maximum power of the photovoltaic system.

- A regulator that makes electrical regulation to protect the batteries against overload.

- Converters of DC voltage.

- AC voltage converters to amplify the power.

- Parabolic collectors are solar collectors that transform direct solar radiation into heat energy that heats a working fluid. The parabolic concentrator reflects the direct solar radiation on the focal line of the dish. In which is the receiver, which is an absorber tube.

An essential feature of these sensors is that they can reach temperatures up to $400^{\circ} \mathrm{C}$ with excellent thermodynamic efficiency. They have applications in both the production of electrical energy and in the heating of water. The suggested mechanism is an ecological technique to provide electricity and distilled water. 


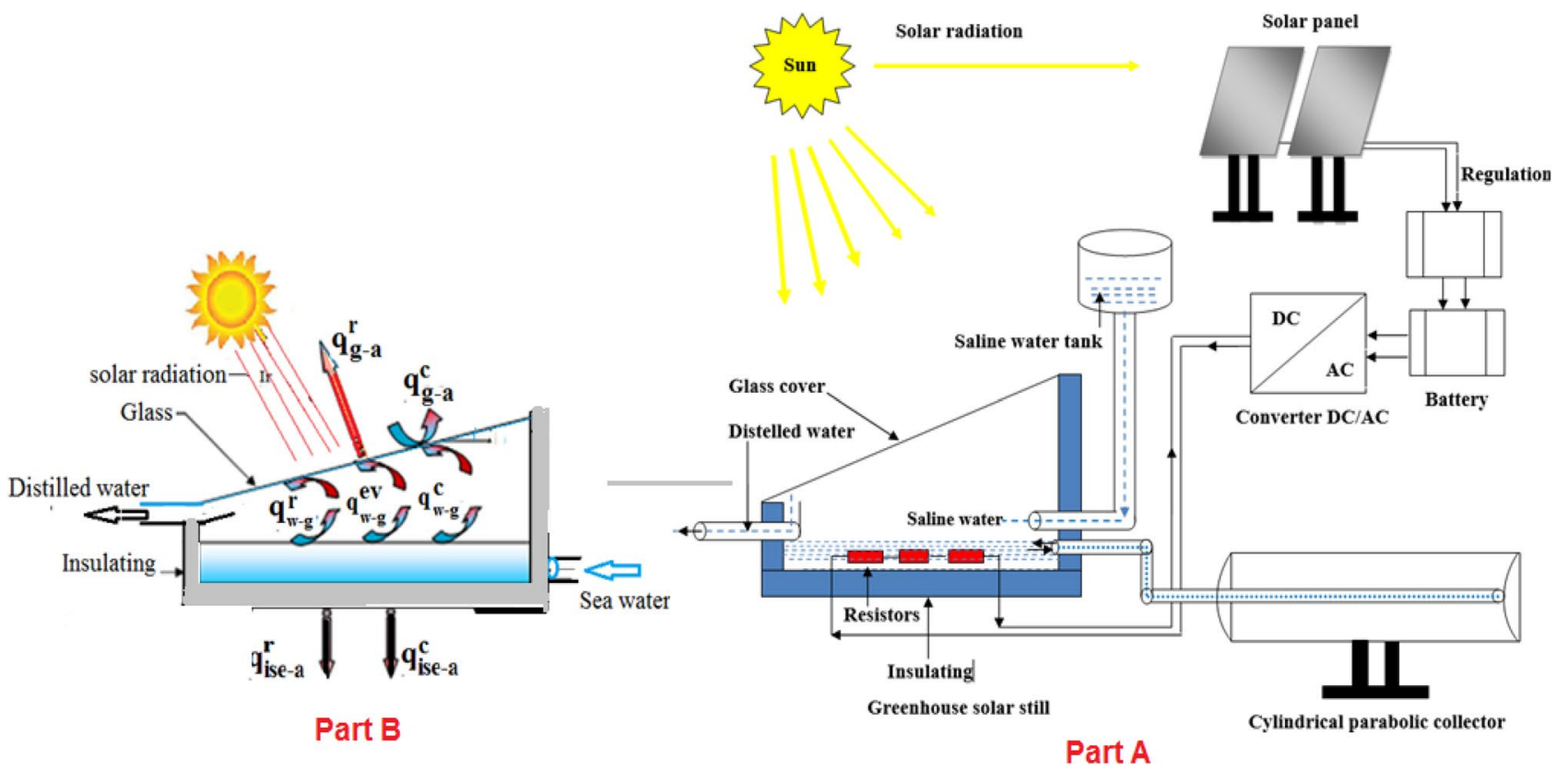

Fig. 1 The hybrid distiller under study

\section{Governing parameters}

\subsection{Parabolic concentrator}

The energy balances for the absorber:

The power absorbed per unit of opening area is written as follows [23]:

$q_{\text {absorbed }}=I \cdot \rho \cdot C \cdot \gamma$

Between the absorber and the glass envelope:

$\frac{d\left(\Delta Q_{A}(z, t)\right)}{d t}=\left(q_{\text {absorbed }}(t)\right)-q_{\text {entre }}(z, t)-q_{\text {utile }}(z, t) \cdot \Delta z$

with:

$q_{\text {inside }}$ : the amount of energy that indicates the heat transfer between the absorber tube and the glass envelope.

$q_{\text {absorbed: }}$ is the amount of solar energy absorbed from thermodynamics we have:

$\Delta Q_{a b s}(z, t)=A_{a b s} \cdot \rho_{a b s} \cdot C_{a b s} \cdot T_{a b s}(z, t)$

$\rho_{\text {abs }}, C_{a b s}$ and $T_{a b s}$ are respectively the density, the specific heat and the temperature of the absorber tube.

Between the glass envelope and the environment: $\rho_{v} \cdot C_{v} \cdot A_{v} \frac{d T_{v}(z, t)}{d t}=q_{\text {interne }}(z, t)-q_{\text {externe }}(z, t)$

$T_{v}(z, 0)=T_{v, \text { initial }}(z)=T_{a m b}(0)$

$\rho_{\mathrm{v}}, C_{\mathrm{v}}$, and $T_{\mathrm{v}}$ are the specific heat density and the temperature of the glass envelope, respectively.

The different heat transfers between the absorber and the heat transfer fluid [23]:

$\Delta Q_{f}(z, t)=A_{a b s} \cdot \rho_{f} \cdot C_{f} \cdot \Delta z \cdot T_{f}(z, t)$

$\rho_{\mathrm{f}}, C_{\mathrm{f}}$, and $T_{\mathrm{f}}$ are the density, specific heat, and temperature of the coolant, respectively.

$\frac{d\left(Q_{f}(z, t)\right)}{d t}=q_{\text {int }}(z, t)-q_{\text {ext }}(z+\Delta z, t) \Delta z$

\subsection{Green house distiller}

Figure 1 (Part B) illustrates the different heat exchanges that occur in a solar still. It is based on four principles, namely the glazing balance, water balance, insulation balance, and the condensate flow). In the transient regime, the equations governing the heat balance at the level of each part of the still are written as follows [24]: 
3.2.1 In the cover

Outside:

$\frac{M_{g}}{2} \frac{c p_{g}}{A_{g}} \frac{d T_{g e}}{d t}+q_{g_{-} a}^{c}+q_{g_{-} a}^{r}=\frac{\lambda_{g}}{e_{g}}\left(T_{g i}-T_{g e}\right)$

Inner face:

$\frac{M_{g}}{2} \frac{c p_{g}}{A_{g}} \frac{d T_{g i}}{d t}+\frac{\lambda_{g}}{e_{g}}\left(T_{g i}-T_{g e}\right)=q_{w_{-} g}^{c}+q_{w_{-} g}^{r}+q_{w_{-} g}^{e v}+p_{g}$

$$
E_{T}=\frac{E_{D C}}{\eta_{B A T}}+\frac{E_{A C}}{\eta_{B A T} \eta_{I N V}}
$$

\subsection{PV generator dimensioning}

$N_{T}=\frac{E_{T}}{G_{m B} \cdot P_{p} \cdot P_{G}}$

3.2.2 In the brine

$M_{w} \frac{c p_{w}}{A_{w}} \frac{d T_{w}}{d t}+q_{w \_g}^{c}+q_{w \_g}^{r}+q_{w \_g}^{e v}=p_{w}+q_{b \_w}^{c}$

3.2.3 In the absorbent tray

$M_{b} \frac{c p_{b}}{A_{b}} \frac{d T_{b}}{d t}+q_{b \_w}^{c}+q_{b \_i s i}^{c d}=p_{b}$

$N_{P}=\frac{N_{T}}{V_{S}}$

\subsection{Autonomy}

$C_{n}(w h)=\frac{E_{T} N}{P_{d}}$

$C_{n}(A h)=\frac{C_{n}(w h)}{V_{B A T}}$

\subsubsection{In the insulation}

Inner face:

$\frac{M_{i s}}{2} \frac{c p_{i s}}{A_{i s}} \frac{d T_{i s i}}{d t}+\frac{\lambda_{i s}}{e_{i s}}\left(T_{i s i}-T_{i s e}\right)=q_{b_{i} i s i}^{c d}$

Outside face:

$\frac{M_{\text {is }}}{2} \frac{c p_{\text {is }}}{A_{\text {is }}} \frac{d T_{\text {ise }}}{d t}+q_{i s \_a}^{c}+q_{i s \_a}^{r}=\frac{\lambda_{i s}}{e_{i s}}\left(T_{i s i}-T_{i s e}\right)$

\subsection{Sizing of the regulator}

$I_{G}=I_{R} \cdot N_{R}$

$I_{R}=\frac{P_{p} \eta_{m}}{V_{m}}$

$I_{C}=\frac{P_{D C}}{V_{b a t m}}+\frac{P_{A C}}{220}$

\subsection{Hybrid distiller}

$I_{R}=\max \left(I_{G}, I_{C}\right)$

$M_{w} \frac{c p_{w}}{A_{w}} \frac{d T_{w}}{d t}+q_{w \_g}^{c}+q_{w \_g}^{r}+q_{w \_g}^{e v}=p_{w}+m c p\left(T_{c c}-T_{w 0}\right)+m c p\left(T_{e l}-T_{w 0}\right)+q_{b \_w}^{c}$

\subsection{Dimensioning of the converter}

$P_{\text {Rinv }} \approx P_{A C}$

The power of all appliances that will be made up of the installation must be determined according to the distillation time [25]:

\subsection{Dimensioning of the wiring}

$E_{A C}=\sum P_{(A C) i} \cdot t_{d i}$

$E_{D C}=\sum P_{(D C) i} \cdot t_{d i}$

(16) $R C=\frac{\rho \cdot L}{S}$ 


\subsubsection{Conversion of the electrical energy into thermal energy}

$Q=m C p \Delta T$

$P=V \cdot R=R \cdot I^{2}$

$Q=P \cdot \Delta t$

$\Delta T=\frac{P \cdot \Delta t}{m C p}$

\subsubsection{Performance}

Satcunanathan and Hansen [26], defined the performance factor $(F p)$ as follows:

$F_{P}=\frac{\text { Daily yield }}{\text { daily incident radiation entrering }}$

\section{Findings and analysis}

\subsection{Analysis}

The temperatures of the brine and water at $14 \mathrm{pm}$ are 140 and $120^{\circ} \mathrm{C}$ (Fig. 2), respectively, due to the added heat

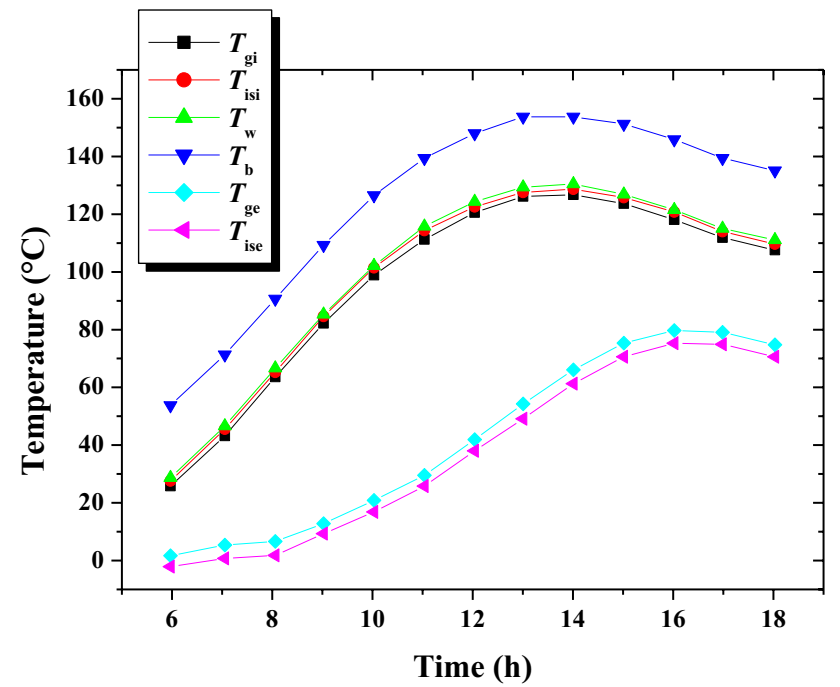

Fig. 2 Temperature variation of elements of the hybrid distiller coupled with a parabolic concentrator, where $T_{\mathrm{gi}}$ : temperature of the inner side of the glass, $T_{\text {isi: }}$ temperature of the inner side of the insulation, $T_{\mathrm{w}}$ : water temperature, $T_{\mathrm{b}}$ : pool temperature, $T_{\mathrm{ge}}$ : temperature of the outer side of the glass, $T_{\text {ise }}$ : temperature of the outer side of the insulation source (the parabolic cylindrical concentrator and the photovoltaic generator and the greenhouse still). These temperatures decreased slowly at $18 \mathrm{pm}$, but they remained at effective values of $100^{\circ} \mathrm{C}$ for the still operation. The result of the hybrid distiller presents an interesting efficiency, despite the evening.

From Fig. 3, the temperatures of the PCC absorber and water in the PCC at $12 \mathrm{pm}$ are 90 and $85^{\circ} \mathrm{C}$, respectively. This result shows that the PCC is an essential element for improving the performance and operation of the hybrid still.

The specific heat of water increases from 10 a.m. to $14 \mathrm{pm}$ and reaches significant values $(4330 \mathrm{~J} / \mathrm{kg} \cdot \mathrm{K})$, as observed in Fig. 4. From 14 pm to 18 pm, the specific heat decreases slowly and takes average values $(4240 \mathrm{~J} / \mathrm{kg} \cdot \mathrm{K})$

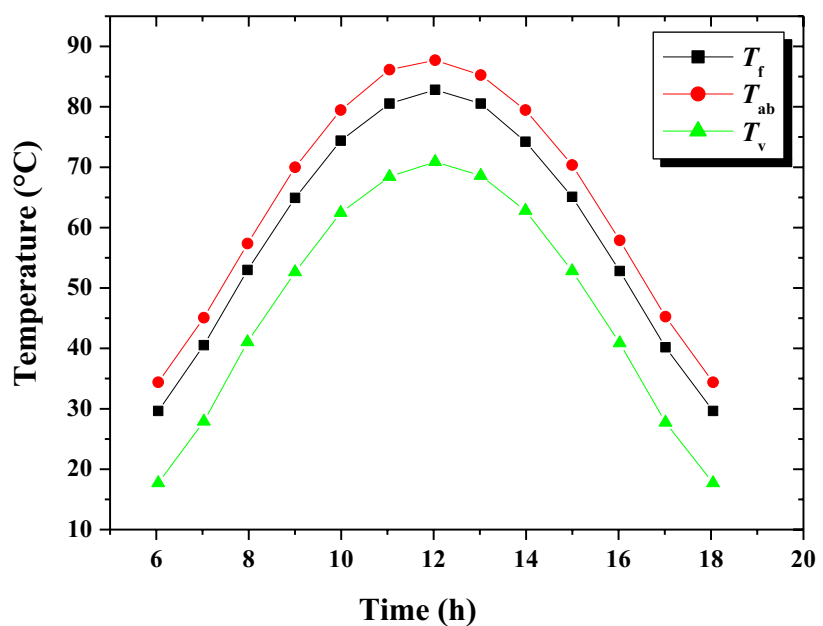

Fig. 3 Changes in the temperature of the parabolic concentrator elements vs. time, where $T_{\mathrm{f}}$ is the fluid temperature (water), $T_{\mathrm{v}}$ : glass temperature, $T_{\mathrm{ab}}$ : absorber temperature

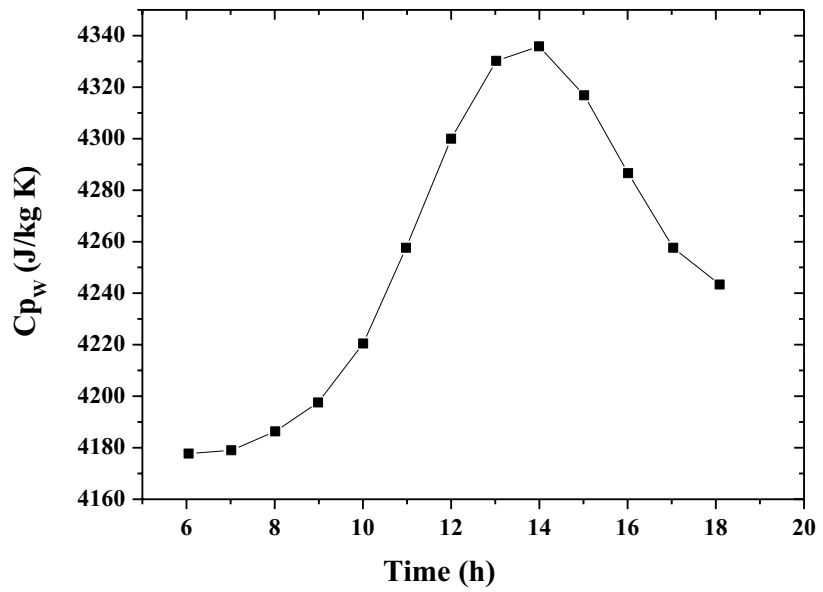

Fig. 4 Specific heat of the hybrid distiller coupled with a parabolic concentrator vs. time 


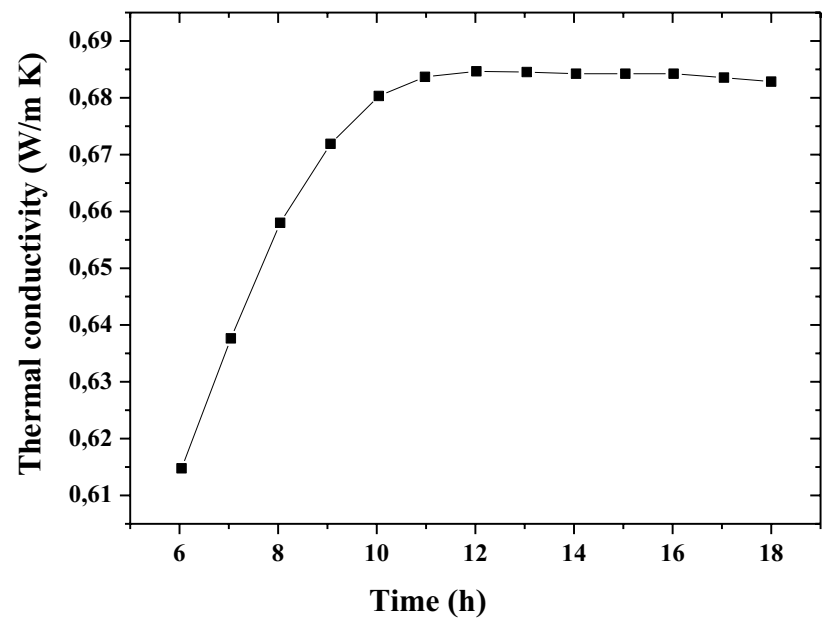

Fig. 5 Thermal conductivity of the hybrid distiller coupled with a parabolic concentrator vs. time

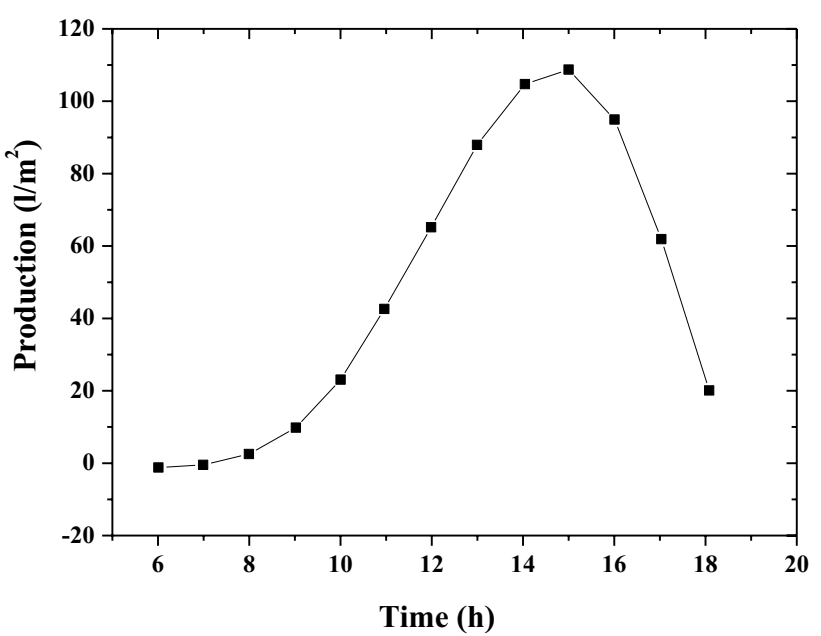

Fig. 6 Production of the hybrid distiller coupled with a parabolic concentrator vs. time

even in the evening. These significant values of the specific heat are due to the temperature, which is proportional to the specific heat.

The results given in Fig. 5 reveal an increase in the thermal conductivity from 9 a.m. to $18 \mathrm{pm}$ until reaching considerable values $(0.68 \mathrm{~W} / \mathrm{m} \cdot \mathrm{K})$. The monotonic thermal conductivity is stable due to the high still temperature.

In addition, an interesting amount in the production of about $100 \mathrm{l} / \mathrm{m}^{2}$ is obtained from 10 a.m. to 14 pm (Fig. 6). However, a decrease in the production to less than $20 \mathrm{l} /$ $\mathrm{m}^{2}$ is observed from $3 \mathrm{pm}$ to $6 \mathrm{pm}$, despite the absence of solar radiation. These values are high because of the temperature of the hybrid system that is generated by several thermal sources.

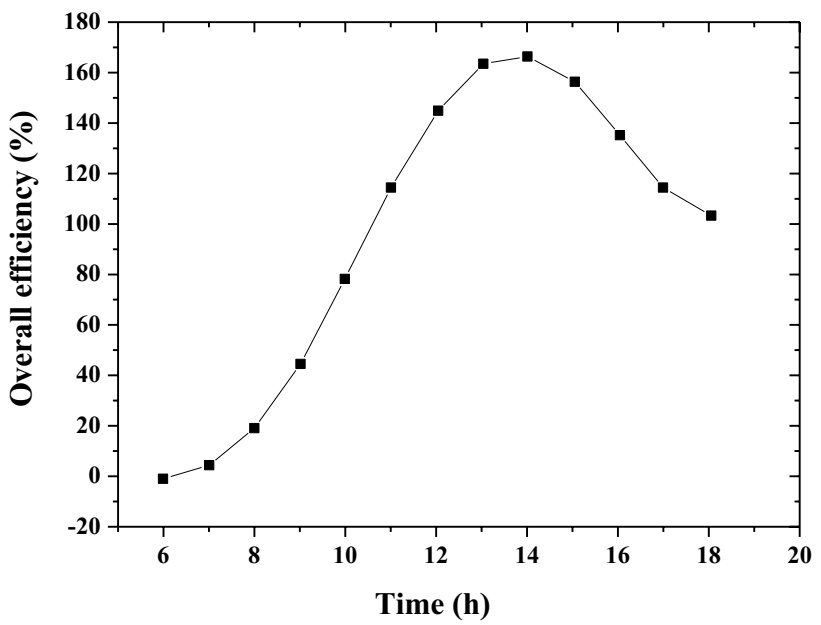

Fig. 7 Overall efficiency of the hybrid distiller coupled with a parabolic concentrator vs. time

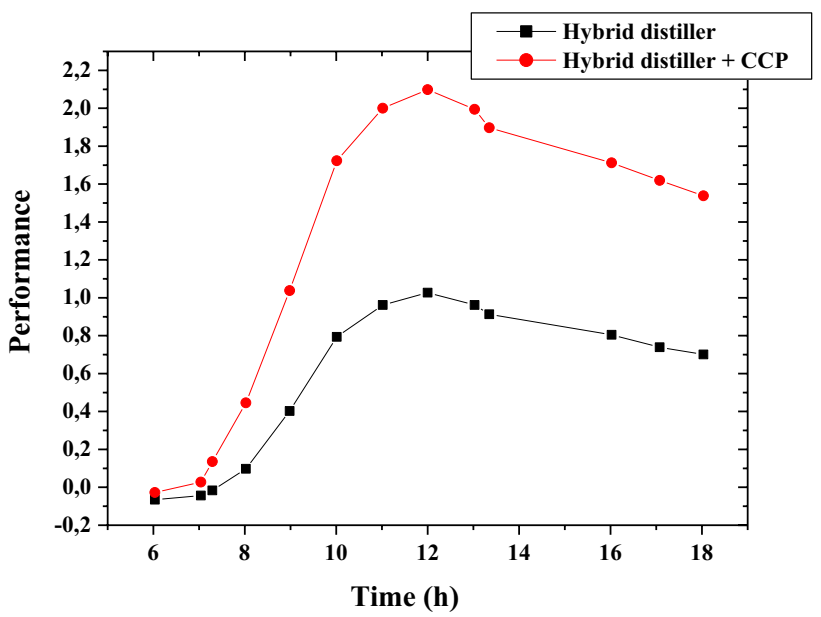

Fig. 8 Performance of distillers $(\mathrm{kg} / \mathrm{kJ})$ vs. time

The overall efficiency picks up interesting values of about $160 \%$ from 10 a.m. to 14 pm (Fig. 7). From 3 pm and until $6 \mathrm{pm}$, the efficiency decreases until 100\% despite the absence of solar radiation. From Fig. 8, the performance reaches the value " 2 " at 9 a.m. and remains high until 13 pm From 2 pm and until 6 pm, it decreases to 1.5 despite the absence of solar radiation. These considerable values are due to the temperature of the hybrid system produced by several thermal sources.

The performance of the hybrid still used alone and that of the hybrid still combined with PCC are illustrated in Fig. 8. From 8 a.m. to $6 \mathrm{pm}$, the performances of the two systems are 1.5 and 2 , respectively. It can be seen that the hybrid still with PCC is more efficient that the hybrid still used alone because of the high temperature of the still. 


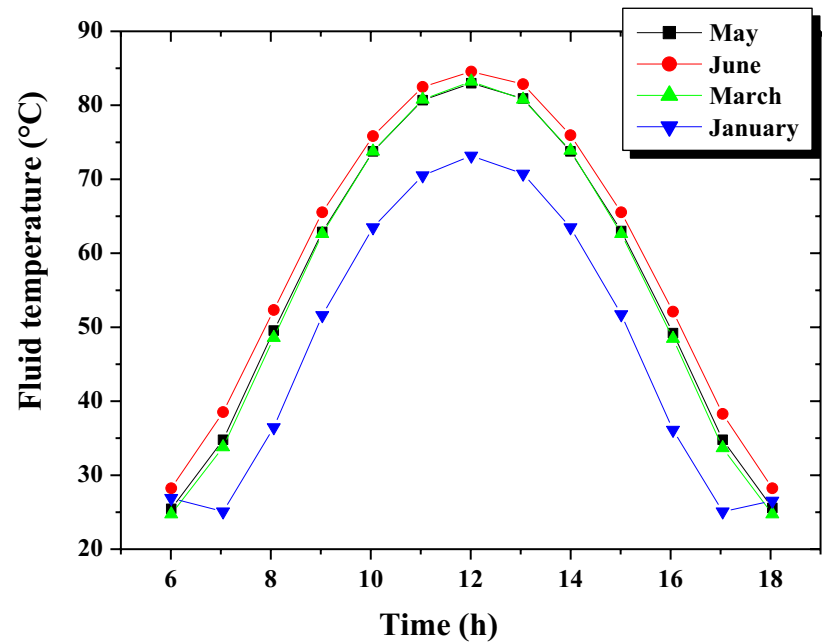

Fig. 9 Monthly variation of the fluid temperature

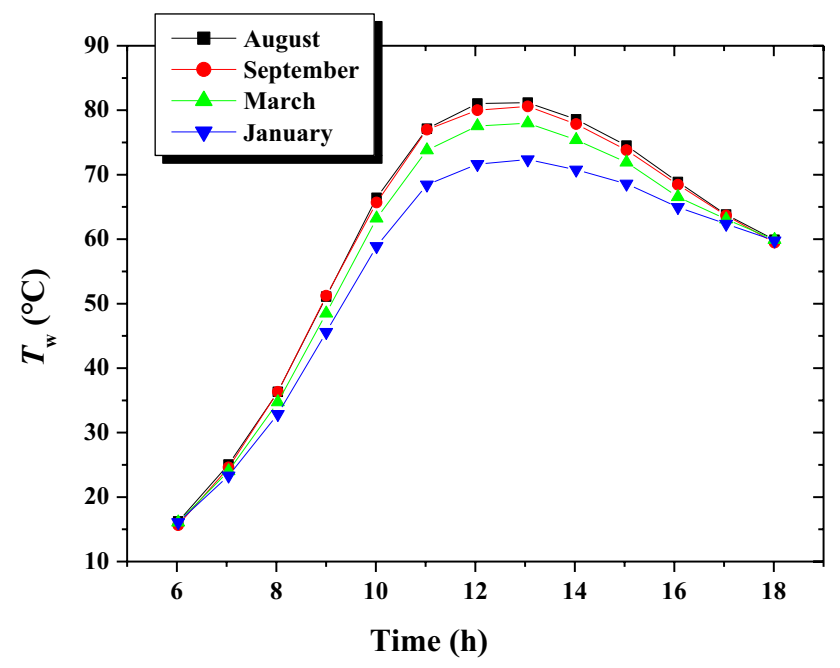

Fig. 10 Monthly variation of the water temperature

Figures 9 and 10 show the temporal variation of the temperatures $T_{\mathrm{f}}$ and $T_{\mathrm{w}}$, respectively, during the months of the year. The highest value of $85^{\circ} \mathrm{C}$ is remarked in August at $12 \mathrm{pm}$ At $14 \mathrm{pm}, T_{\mathrm{f}}$ and $T_{\mathrm{w}}$ begin to decrease due to the weak solar rays. At $18 \mathrm{pm}, T_{\mathrm{w}}$ remains high (about $60^{\circ} \mathrm{C}$ ) due to the storage system of the photovoltaic generator. However, the value $T_{\mathrm{f}}$ is $10^{\circ} \mathrm{C}$ because of the absence of solar radiation.

This work aims to develop and improve the productivity and efficiency of solar still. The results obtained illustrate the importance of the proposed system since the production of the greenhouse still does not exceed $40 \mathrm{l} / \mathrm{m}^{2}$. The proposed system allowed reaching $100 \mathrm{l} / \mathrm{m}^{2}$ of production and $160 \%$ for the efficiency.
Table 1 Standard deviation from the mean values in Fig. 9

\begin{tabular}{llclr}
\hline & January & March & May & \multicolumn{1}{l}{ June } \\
\hline Mean & 47.8334 & 56.5229 & 56.4754 & 59.0006 \\
Median & 51.6762 & 62.7798 & 62.7981 & 65.2207 \\
Standard deviation & 19.0744 & 21.581 & 21.8885 & 20.9498 \\
Total & 621.8345 & 734.7972 & 734.1804 & 767.0076 \\
Min & 24 & 25.3223 & 25 & 27.7648 \\
Max & 73.199 & 83.0915 & 83.4664 & 84.5201 \\
\hline
\end{tabular}

Table 2 Standard deviation from the mean values in Fig. 10

\begin{tabular}{lrrrc}
\hline & January & March & August & September \\
\hline Mean & 55.3067 & 57.9503 & 60.0037 & 59.5523 \\
Median & 62.5908 & 63.4429 & 66.3481 & 65.7185 \\
Standard deviation & 19.3843 & 20.8972 & 21.6733 & 21.5078 \\
Total & 718.9873 & 753.3533 & 780.0478 & 774.1794 \\
Min & 16.0056 & 16.0329 & 16.0024 & 16.0102 \\
Max & 72.7701 & 78.0736 & 81.1612 & 80.5 \\
\hline
\end{tabular}

The temperatures of the still are high and slowly decrease even in the evening, due to the various heat sources combined with the still. This combination of heat sources reduces the influence of meteorological parameters. The results of Fig. 9 clearly show that the performance of the hybrid still combined with PCC is higher than that of the hybrid still without PCC. This comparison allowed us to deduce the importance of coupling of external thermal sources.

Tables 1 and 2 summarize the standard deviation from the mean values in Figs. 9 and 10, respectively. According to the calculations, the standard deviation of the temperature values is similar in the months of the year. It is also observed that the calculation errors do not exceed $6{ }^{\circ} \mathrm{C}$, despite the high temperature.

\subsection{Discussion}

Sampathkumar et al. [27] performed a comparison between the productivity of different types of solar still. Their result showed that the distiller coupled with concentrators has higher productivity and efficiency than the other stills. Mathioulakis and Belessiotis [28] studied the coupling of the still with a water reservoir, which acts as a thermal buffer. They found that the productivity of the coupled system is double that of the single system. Significant increases in the productivity of distilled water were obtained not only during the day but also during the nighttime operation. The system allowed reaching three times the productivity of the solar system alone. They have been shown that this design also leads to a significant 
distilled water production, due to the high temperatures of the pond water.

Badran and Al-Tahaineh [29] studied a single slope solar still with mirrors attached to its inner sides and coupled to a flat plate collector. They found that pairing a solar collector with a still increased the productivity by $36 \%$. Voropoulos et al. [30] found that the coupling of a solar still with a hot water tank, generally doubles the production of distilled water over a period of $24 \mathrm{~h}$, due to the continuous heating of the water in the basin from the water from the tank. The hybrid system has the power to supply the desalinated water with the hot water and lead to significantly high-water productivity day and night. Voropoulos et al. [31] proposed an asymmetric greenhouse type solar still, whose basin was connected with a hot water storage tank, thus ensuring heat transfer. They found that this design leads to higher water outflows as the water temperature increases. In addition, the rate of water production was almost constant throughout the period.

The previous papers show that the coupling increases the productivity and ensures a thermal stability of the operation, for $24 \mathrm{~h}$. The previously studied systems only exploit the coupling of thermal sources. However, our proposed system operates for all forms of solar electric power with storage and thermal power with concentrator. The system suggested hear has higher productivity, efficiency, and stability than the system coupled only with thermal sources.

\section{Conclusion}

An intensive research has been done to improve the productivity of the solar still. Thermal source coupling systems occupy a large margin of this research, but they are based only on plant sensors and passive cascade systems. In this study, a coupling system was proposed which exploits all forms of solar, electric or thermal radiation conversions for the development of solar still. The results showed also that the water temperatures $\left(T_{\mathrm{w}}\right)$ were equal to $120^{\circ} \mathrm{C}$ and $110{ }^{\circ} \mathrm{C}$ at $14 \mathrm{pm}$ and $18 \mathrm{pm}$ respectively. So, the temperature decreased slowly due to the autonomy of the photovoltaic system.

This high temperature increased the productivity of the hybrid still combined with a PCC until reaching $100 \mathrm{l} / \mathrm{m}^{2}$. In addition, the performance of the hybrid still was $2 \mathrm{~kJ} /$ $\mathrm{kg}$, and the overall efficiency was $160 \%$. The values of the above parameters illustrate the reliability of the coupling system for solar distillation. Another advantage presented by the hybrid still with PCC is the production in January, which reached $50 \mathrm{l} / \mathrm{m}^{2}$, despite the influence of meteorological parameters and low solar radiation.

\section{Compliance with ethical standards}

Conflict of interest The authors declare that they have no conflict of interest.

Open Access This article is licensed under a Creative Commons Attribution 4.0 International License, which permits use, sharing, adaptation, distribution and reproduction in any medium or format, as long as you give appropriate credit to the original author(s) and the source, provide a link to the Creative Commons licence, and indicate if changes were made. The images or other third party material in this article are included in the article's Creative Commons licence, unless indicated otherwise in a credit line to the material. If material is not included in the article's Creative Commons licence and your intended use is not permitted by statutory regulation or exceeds the permitted use, you will need to obtain permission directly from the copyright holder. To view a copy of this licence, visit http://creativecommons. org/licenses/by/4.0/.

\section{References}

1. Hassan ESF (1998) Solar distillation: a promising alternative for water provision with free energy, simple technology and a clean environment. Desalination 116:45-56. https://doi.org/10.1016/ S0011-9164(98)00056-3

2. Kaushik S, Ranjan K, Panwar N (2013) Optimum exergy efficiency of single-effect ideal passive solar stills. Energ Effi 6:595-606. https://doi.org/10.1007/s12053-013-9194-x

3. Manokar AM, Winston DP, Kabeel A, Sathyamurthy R (2018) (2018) Sustainable fresh water and power production by integrating PV panel in inclined solar still. Journal of Cleaner Production 172:2711-2719. https://doi.org/10.1016/j.jclep ro.2017.11.140

4. Frick G, Von Sommerfeld J (1973) (1973) Solar stills of inclined evaporating cloth. Sol Energy 14:427-431. https://doi. org/10.1016/0038-092X(73)90021-2

5. Tiwari G, Sharma S, Sodha M (1984) Performance of a double condensing multiple wick solar still. Energy Convers Manage 24:155-159. https://doi.org/10.1016/0196-8904(84)90028-1

6. Somwanshi A, Tiwari AK (2014) Performance enhancement of a single basin solar still with flow of water from an air cooler on the cover. Desalination 352:92-102. https://doi.org/10.1016/j. desal.2014.08.011

7. Hosseini A, Banakar A, Gorjian S (2018) Development and performance evaluation of an active solar distillation system integrated with a vacuum-type heat exchanger. Desalination 435:45-59. https://doi.org/10.1016/j.desal.2017.12.031

8. Elbar ARA, Hassan H (2019) Experimental investigation on the impact of thermal energy storage on the solar still performance coupled with PV module via new integration. Sol Energy 184:584-593. https://doi.org/10.1016/j.solener.2019.04.042

9. Elbar ARA, Hassan H (2020) Enhancement of hybrid solar desalination system composed of solar panel and solar still by using porous material and saline water preheating. Sol Energy 204:382-394. https://doi.org/10.1016/j.solener.2020.04.058

10. Mazraeh A, Babayan M, Yari M, Sefidan AM, Saha SC (2018) Theoretical study on the performance of a solar still system integrated with PCM-PV module for sustainable water and power generation. Desalination 443:184-197. https://doi. org/10.1016/j.desal.2018.05.024

11. Hedayati-Mehdiabadi E, Sarhaddi F, Sobhnamayan F (2020) Exergy performance evaluation of a basin-type double-slope 
solar still equipped with phase-change material and PV/T collector. Renewable Energy 145:2409-2425. https://doi. org/10.1016/j.renene.2019.07.160

12. Manokar AM, Winston DP, Kabeel A, El-Agouz S, Sathyamurthy R, Arunkumar T, Madhu B, Ahsan A (2018) Integrated PV/T solar still-A mini-review. Desalination 435:259-267. https://doi. org/10.1016/j.desal.2017.04.022

13. Pounraj P, Winston DP, Kabeel A, Kumar BP, Manokar AM, Sathyamurthy R, Christabel SC (2018) Experimental investigation on Peltier based hybrid PV/T active solar still for enhancing the overall performance. Energy Convers Manage 168:371-381. https://doi.org/10.1016/j.enconman.2018.05.011

14. Saeedi F, Sarhaddi F, Behzadmehr A (2015) Optimization of a $\mathrm{PV} / \mathrm{T}$ (photovoltaic/thermal) active solar still. Energy 87:142152. https://doi.org/10.1016/j.energy.2015.04.062

15. Johnson A, Mu L, Park YH, Valles DJ, Wang H, Xu P, Kota K, Kuravi $S$ (2019) (2019) A thermal model for predicting the performance of a solar still with fresnel lens. Water 11:1860. https:// doi.org/10.3390/w11091860

16. Winston DP, Pounraj P, Manokar AM, Sathyamurthy R, Kabeel A (2018) Experimental investigation on hybrid PV/T active solar still with effective heating and cover cooling method. Desalination 435:140-151. https://doi.org/10.1016/j.desal.2017.11.007

17. Rajaseenivasan T, Prakash R, Vijayakumar K, Srithar K (2017) (2017) Mathematical and experimental investigation on the influence of basin height variation and stirring of water by solar PV panels in solar still. Desalination 415:67-75. https:// doi.org/10.1016/j.desal.2017.04.010

18. Rahbar N, Esfahani JA, Asadi A (2016) An experimental investigation on productivity and performance of a new improved design portable asymmetrical solar still utilizing thermoelectric modules. Energy Convers Manage 118:55-62. https://doi. org/10.1016/j.enconman.2016.03.052

19. Kargarsharifabad H, Mamouri SJ, Shafii M, Rahni MT (2013) Experimental investigation of the effect of using closed-loop pulsating heat pipe on the performance of a flat plate solar collector. Journal of Renewable and Sustainable Energy 5:013106. https://doi.org/10.1063/1.4780996

20. Xiao L, Shi R, Wu S-Y, Chen Z-L (2019) Performance study on a photovoltaic thermal (PV/T) stepped solar still with a bottom channel. Desalination 471:114129. https://doi.org/10.1016/j. desal.2019.114129

21. Alipanah F, Rahbar N (2018) CFD simulation and second law analysis of weir-type cascade solar stills with different number and dimensions of steps. Desalination and Water Treatment 104:15-27. https://doi.org/10.5004/dwt.2018.21925
22. Rahbar N, Asadi A, Fotouhi-Bafghi E (2018) Performance evaluation of two solar stills of different geometries: tubular versus triangular: experimental study, numerical simulation, and second law analysis. Desalination 443:44-55. https://doi.org/10.1016/j. desal.2018.05.015

23. Garcia-Valladares O, Velazquez N (2009) (2009) Numerical simulation of parabolic trough collector: improvement using counter flow concentric circular heat exchangers. Int J Heat Mass Transf 52:597-609. https://doi.org/10.1016/j.ijheatmasstrans fer.2008.08.004

24. Velmurugan V, Gopalakrishnan M, Raghu R, Srithar K (2008) Single basin solar still with fin for enhancing productivity. Energy Convers Manage 49:2602-2608. https://doi.org/10.1016/j.encon man.2008.05.010

25. Nurfaidah Y, Wibawa IPD, Aprilia BND, Ekaputri C, Reza M (2019) Analysis of smart house power savings with on-grid photovoltaic power system. J Phys Conf Ser 1367(1):012047. https://doi. org/10.1088/1742-6596/1367/1/012047/meta

26. Satcunanathan ETH (1973) An investigation of some of the parameters involved in solar distillation. Solair Energy 14(3):353-363. https://doi.org/10.1016/0038-092X(73)90102-3

27. Sampathkumar K, Arjunan TV, Pitchandi P (2010) Active solar distillation-a detailed review. Renew Sustain Energy Rev 14:1503-1526. https://doi.org/10.1016/j.rser.2010.01.023

28. Mathioulakis E, Belessiotis V (2003) (2003) Integration of solar still in a multi-source, multi-use environment. Sol Energy 75:403-411. https://doi.org/10.1016/j.solener.2003.07.006

29. Badran OO, Al-Tahaineh HA (2005) The effect of coupling a flat-plate collector on the solar still productivity. Desalination 183(137):142. https://doi.org/10.1016/j.desal.2005.02.046

30. Voropoulos K, Mathioulakis E, Belessiotis V (2001) Experimental investigation of a solar still coupled with solar collectors. Desalination 138:103-110. https://doi.org/10.1016/S0011 -9164(01)00251-X

31. Voropoulos K, Mathioulakis E, Belessiotis V (2003) Experimental investigation of the behavior of a solar still coupled with hot water storage tank. Desalination 156:315-322. https://doi. org/10.1016/S0011-9164(98)00056-3

Publisher's Note Springer Nature remains neutral with regard to jurisdictional claims in published maps and institutional affiliations. 